\title{
Assessment of Industrial Risks Related to Steam Production in a Thermal Production Service: Case of the Ouaga North of Burkina Faso Thermal Production Service
}

\author{
Madjoyogo Hervé Sirima1,2, Betaboale Naon ${ }^{3}$, Frédéric Bationo ${ }^{4}$ \\ ${ }^{1}$ Institute of Industrial and Textile Systems Engineering, Polytechnic School of Ouagadougou, Burkina Faso \\ ${ }^{2}$ Center for Applied Research in Industrial Systems Engineering, Ouagadougou, Burkina Faso \\ ${ }^{3}$ Study and Research Group in Mechanics, Energetics and Industrial Technics, University Institute of Technology, Nazi BONI \\ University, Bobo-Dioulasso, Burkina Faso \\ ${ }^{4}$ Mechanization Department, Research Institute in Applied and Technological Sciences, National Center for Scientific and \\ Technological Research, Ouagadougou, Burkina Faso \\ Email: madjoyogo2@yahoo.fr, betaboale@yahoo.fr
}

How to cite this paper: Sirima, M.H. Naon, B. and Bationo, F. (2021) Assessment of Industrial Risks Related to Steam Production in a Thermal Production Service: Case of the Ouaga North of Burkina Faso Thermal Production Service. World Journal of Engineering and Technology, 9, 916-928.

https://doi.org/10.4236/wjet.2021.94063

Received: August 27, 2021

Accepted: November 27, 2021

Published: November 30, 2021

Copyright $\odot 2021$ by author(s) and Scientific Research Publishing Inc. This work is licensed under the Creative Commons Attribution International License (CC BY 4.0).

http://creativecommons.org/licenses/by/4.0/

\begin{abstract}
In this work, we have focused on the risks emanating from the steam production process in a thermal production department with a view to reducing the occurrence of unwanted events. The practical aspect of this study is to ensure the well-being of production actors and the surrounding population. Subsequently, we opted for fault tree analysis and HAZOP, which are tools for studying the probabilities of occurrence of unwanted events in the operation of industrial thermal installations. In addition, in the process of steam production, it emerges that pressure and temperature remain the most important parameters to monitor in order to reduce the risks associated with chemicals but especially with steam circuits.
\end{abstract}

Keywords

Fault Tree, Evaluation, HAZOP, Industrial Risk, Steam

\section{Introduction}

The production of steam intended for the sterilization of certain agro-food [1] [2] products and biomedical materials, as well as for the superheating of Heavy Fuel Oil [3] [4], is not without risk. Since said vapor is produced at high temperatures and pressures. 
Steam production facilities use water that has undergone specific treatment. This allows the water to have a higher quality recommended in the steam production process. The treatment confers recommended properties and requires much more care. The overheating of the Heavy Fuel Oil with the help of steam gives it a higher quality that is to say makes it lighter. This allows it easy to use in thermal power stations by a changeover with Distillate Diesel Oil [3] [4].

The risks emanating from steam production are chemical and physical in nature, given that overheating or sterilization process employed is natural convection. This convection process is a transfer of coolant.

The objective of this work is the analysis of these different risks which require prevention [5] [6]. This analysis will allow perfect control of the steam production system at full load, in this case, the various parameters such as temperature and pressure.

\section{Materials and Methods}

The materials entering the water treatment namely the Diaposime B117 and the salt $(\mathrm{NaCl})$ are transferred continuously, from their respective supply tanks to the coils where they combine with the water to give the end product which is treated water.

According to the rule, the Diaposime B117 must always be greater than or equal to the $\mathrm{NaCl}$ introduced into the coils to avoid a risk of explosion. A complete design plan would include many other details such as the effects of pressure, reaction and reactant temperature, agitation, reaction time, compatibility of the Diaposime $\mathrm{B} 117$ pumps and $\mathrm{NaCl}$, etc. ...for the purposes of this study, they are ignored but they will be taken into account at the level of the fault tree. The part of the system retained for HAZOP review is the pipe from the Diaposime B117 supply tank to the boiler, including its transfer pump. The design intent for this part is to transfer, continuously, the Diaposime B117 from the reservoir to the coils, at a rate greater than that of $\mathrm{NaCl}$. Based on the suggested elements, the design intent is illustrated in Figure 1 below.

The quantity of Diaposime B117 must always be greater than that of $\mathrm{NaCl}$ to avoid any risk of explosion.

The guide words mentioned on the sheets as well as those proposed during the preparatory work are then applied in turn to each of the elements of the installation studied, and the results are recorded on the same HAZOP worksheets.

As an exception, the reporting method is used and only significant deviations are recorded. After analyzing each of the guide words for each of the equipment concerned in this part of the installation, another part, namely the $\mathrm{NaCl}$ transfer pipe is taken into account and the process is repeated. In addition, the risk analysis by HAZOP method will lead us to use suitable evaluations tables of the level of severity of the unwanted events as illustrated in Table 1 and Table 2, and of the probabilities of occurrence of said events mentioned in Table 3.

Finally, all the different parts of the installation are examined in the same way and the results are recorded. 


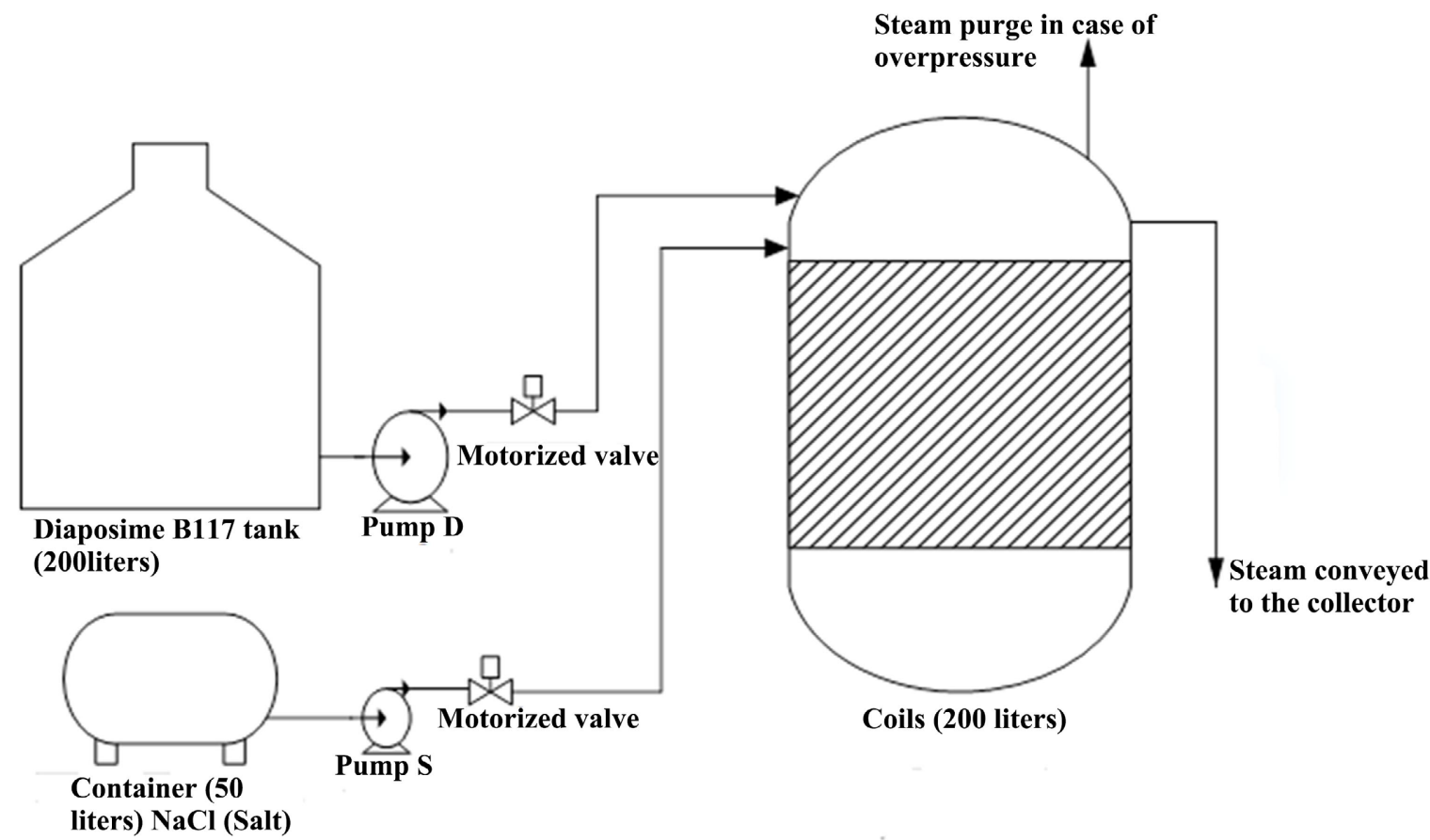

Figure 1. Automatic water treatment device.

Table 1. Severity level (G) of unwanted events (HAZOP).

\begin{tabular}{|c|c|c|}
\hline Levels & Coefficients & Definitions \\
\hline Minor consequences & 1 & $\begin{array}{l}\text { - The tank will exceed the fill limit; } \\
\text { - Presence of impurities. }\end{array}$ \\
\hline $\begin{array}{l}\text { Significant } \\
\text { consequences }\end{array}$ & 2 & $\begin{array}{l}\text { - Possible reduction in yield; } \\
\text { - The product will contain far too many diaposime } \\
\text { B117. }\end{array}$ \\
\hline $\begin{array}{l}\text { Critical or serious } \\
\text { consequences }\end{array}$ & 3 & $\begin{array}{l}\text { - No flow of diaposime B117 in the coils; } \\
\text { - Explosion. }\end{array}$ \\
\hline $\begin{array}{l}\text { Catastrophic } \\
\text { consequences }\end{array}$ & 4 & $\begin{array}{l}\text { - Contamination of the supply tank by reflux of the } \\
\text { reaction material; } \\
\text { - Insufficient net positive section, possible turbulence } \\
\text { and risk of explosion and inadequate flow. }\end{array}$ \\
\hline $\begin{array}{l}\text { External catastrophic } \\
\text { consequences }\end{array}$ & 5 & $\begin{array}{l}\text { - Environmental contamination; } \\
\text { - Explosion or risk of explosion. }\end{array}$ \\
\hline
\end{tabular}

\section{Probability of occurrence $(\mathrm{P})$ :}

Let " $\Omega$ " be the universe of contingencies, that is of cases are likely to occur. We have 15 contingencies (HAZOP worksheets Tables 5-8) grouped into 6 events. That is:

- A: "Acceptable situation/Over";

- B: "Unacceptable situation/In addition to";

- C: "Unacceptable situation/Do not do";

- D: "Unacceptable situation/Other than"; 
- E: "Unacceptable situation/Less than";

- F: "Unacceptable situation/Inverse".

From the above, the cardinals of the various events are therefore recorded in the table of probabilities of occurrence.

Optimal operation of the boiler/steam circuit assembly of the various generating sets of the Ouaga Nord Thermal Production Department requires a reduction in the risks that may occur [5]-[10]. A graphical representation of the combinations of possible system failures that lead to the dysfunctions of interest.

In addition, this leads us to the analysis of the architecture through a qualitative and/or quantitative analysis [5] [6]:

- The research for weak points in the network;

- Research into the impact of the maintenance policy on its performance;

- The study of the cost performance compromise by comparisons of architecture and maintenance policy.

Table 2. Severity level of unwanted events.

\begin{tabular}{|c|c|c|}
\hline Levels & Coefficients & Definitions \\
\hline Minor consequences & 1 & $\begin{array}{l}\text { - No personal injury; } \\
\text { - Discomfort at work; } \\
\text { - Destruction of property that does not jeopardize } \\
\text { the integrity of the system. }\end{array}$ \\
\hline $\begin{array}{l}\text { Significant } \\
\text { consequences }\end{array}$ & 2 & $\begin{array}{l}\text { - Slight injury or limited intoxication of individuals } \\
\text { by a low-toxic product; } \\
\text { - Contamination of the order of the permissible } \\
\text { annual dose; } \\
\text { - Destruction of equipment resulting in system } \\
\text { shutdown; } \\
\text { - Exposure to high level nuisances (noise, vibration, } \\
\text { etc.). }\end{array}$ \\
\hline $\begin{array}{l}\text { Critical or serious } \\
\text { consequences }\end{array}$ & 3 & $\begin{array}{l}\text { - One or more individuals injured or intoxication } \\
\text { limited by a toxic product; } \\
\text { - Contamination by a dose resulting in medical } \\
\text { treatment; } \\
\text { - Pollution of the environment by a weakly toxic } \\
\text { product or a small quantity of a toxic product; } \\
\text { - Irreversible loss of important information. }\end{array}$ \\
\hline $\begin{array}{l}\text { Internal catastrophic } \\
\text { consequences }\end{array}$ & 4 & $\begin{array}{l}\text { - Several people were seriously injured or dead; } \\
\text { - Environmental pollution by significant or repeated } \\
\text { emission of a very toxic product; } \\
\text { - Complete destruction of the system. }\end{array}$ \\
\hline $\begin{array}{l}\text { External catastrophic } \\
\text { consequences }\end{array}$ & 5 & $\begin{array}{l}\text { Same as above except that the environmental impacts } \\
\text { of the system are very significant. }\end{array}$ \\
\hline
\end{tabular}

With regard to the probability of occurrence of unwanted events, the rating grid is mentioned in Table 3 below. 
Table 3. Levels of probability of occurrence.

\begin{tabular}{ccc}
\hline Levels & Coefficients $(\boldsymbol{c})$ & Definitions \\
\hline Very low & 1 & $\boldsymbol{p}<10^{-6}$ \\
& 2 & $10^{-6}<\boldsymbol{p}<10^{-4}$ \\
Once a year $<\boldsymbol{p}<1$ time per month \\
\hline Low & 3 & $10^{-4}<\boldsymbol{p}<10^{-2}$ \\
\hline Fedium & 4 & 1 time per month $<\boldsymbol{p}<1$ time per week \\
\hline Frequent & 4 & $10^{-3}<\boldsymbol{p}<10^{-1}$ \\
& & 1 time per day $<\boldsymbol{p}<1$ time per hour \\
\hline Very frequent & 5 & $10^{-1}<\boldsymbol{p}$ \\
& & $\boldsymbol{p}<1$ time per day \\
\hline
\end{tabular}

\section{Results Anddiscussions}

\subsection{Risk Assessment of Chemical Components Used in Water Treatment by the HAZOP Method}

The cardinal of the 15 contingencies is therefore: Card $\Omega=15$ (Table 4).

HAZOP Worksheets [3] [4] [5] [6]:

Table 4. Probabilities of occurrence of contingencies.

\begin{tabular}{|c|c|c|}
\hline Events & Cardinals & Probabilities of occurrence \\
\hline $\mathrm{A}$ & Card A = 2 & $P(\mathrm{~A})=\frac{\operatorname{card} \mathrm{A}}{\operatorname{card} \Omega}=\frac{2}{15}=0.133$ \\
\hline $\mathrm{B}$ & Card B $=6$ & $P(\mathrm{~B})=\frac{\operatorname{card} \mathrm{B}}{\operatorname{card} \Omega}=\frac{6}{15}=0.4$ \\
\hline $\mathrm{C}$ & Card C $=2$ & $P(\mathrm{C})=\frac{\operatorname{card} \mathrm{C}}{\operatorname{card} \Omega}=\frac{2}{15}=0.133$ \\
\hline $\mathrm{D}$ & Card D $=2$ & $P(\mathrm{D})=\frac{\operatorname{card} \mathrm{D}}{\operatorname{card} \Omega}=\frac{2}{15}=0.133$ \\
\hline $\mathrm{E}$ & Card E $=2$ & $P(\mathrm{E})=\frac{\operatorname{card} \mathrm{E}}{\operatorname{card} \Omega}=\frac{2}{15}=0.133$ \\
\hline $\mathrm{F}$ & Card F = 1 & $P(\mathrm{~F})=\frac{\operatorname{card} \mathrm{F}}{\operatorname{card} \Omega}=\frac{1}{15}=0.067$ \\
\hline
\end{tabular}

The quantification of the various failures was carried out with the collaboration of the other members of the team namely: SIRIMA Madjoyogo Herve (SMH), Chief Operating Officer (CE); Head of the Laboratory (CL); Head of Electrical Maintenance Division (CDME); Head of Mechanical Maintenance Division (CDMM); Charged with the CMMS (CG). The perfect demonstration of these analyzes is illustrated in Tables 5-8 below. 
Table 5. HAZOP worksheets $1 / 4$.

Title of the study: Water treatment process

Drawing $\mathrm{N}^{\circ}$ :

Line-up: SMH, CE, CL, CDME, CDMM, CG,

Considered part: Transfer duct of supply tank from Diaposime to coils

Material: Diaposime B117

Source: Diaposime B117 Tank

Operating parameters: Pressure and temperature

$\mathrm{N}^{\circ} \begin{aligned} & \text { Word } \\ & \text { guide }\end{aligned}$ Element Deviation Causes Consequences $\begin{aligned} & \text { Barriers } \\ & \text { security }\end{aligned}$ G $\quad \mathrm{P} \quad \mathrm{R} \quad$ Events $\quad$ Correctives action

Activity: Transfer continuously at a rate greater than that of $\mathrm{NaC}$

Destination: Streamers

Plan the installation for the

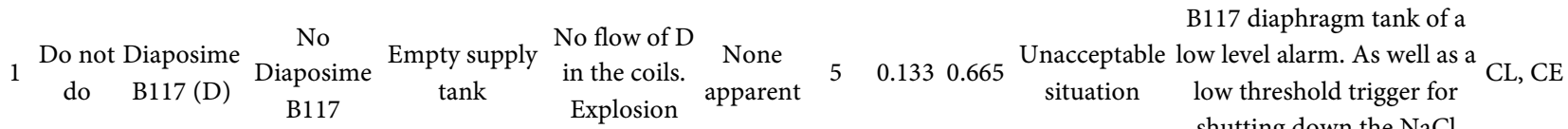
shutting down the $\mathrm{NaCl}$

(Salt) pump.

Flow measurement of

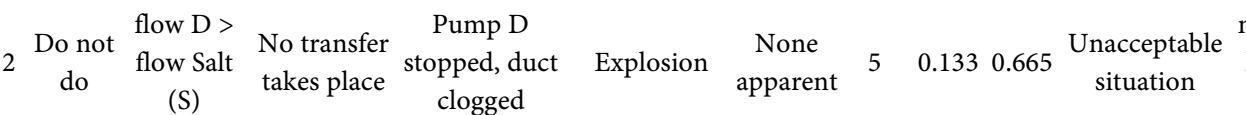
material D, as well as a low CDME, level alarm and triggering $\mathrm{CDMM}$, of the S pump in case of $\mathrm{CE}$ low flow

\begin{tabular}{|c|c|c|c|c|c|c|c|c|c|c|}
\hline $\begin{array}{l}\text { More } \\
\text { than }\end{array}$ & Material D & $\begin{array}{c}\text { Material } \\
\text { tank D full }\end{array}$ & $\begin{array}{l}\text { Filling the } \\
\text { tank from a } \\
\text { tank, so that } \\
\text { the ability is } \\
\text { insufficient }\end{array}$ & $\begin{array}{l}\text { The tank is } \\
\text { going exceed } \\
\text { the limit } \\
\text { filling }\end{array}$ & $\begin{array}{c}\text { None } \\
\text { apparent }\end{array}$ & 2 & 0.133 & 0.266 & $\begin{array}{c}\text { Acceptable } \\
\text { situation }\end{array}$ & $\begin{array}{c}\text { Anticipate an alarm high } \\
\text { level if not determined } \\
\text { previously }\end{array}$ \\
\hline
\end{tabular}
insufficient.

Table 6. HAZOP Worksheets 2/4.

Title of the study: Water treatment process

Drawing $\mathrm{N}^{\circ}$ :

Line-up: CE, CL, CDME, CDMM, CG, SMH

\section{Worksheets: $2 / 4$}

Date: $26 / 05 / 2021$

Meeting date: 20/05/2021

Party considered: Transfer duct from the supply tank of the diaposime to the boilers

Material: Diaposime B117

Source: Diaposime B117 tank

Activity: Transfer continuously at a rate greater than that of $\mathrm{NaCl}$

Destination: Streamers

Operating parameters: Pressure, temperature and flow

\begin{tabular}{|c|c|c|c|c|c|c|c|c|c|c|}
\hline $\mathrm{N}^{\circ} \begin{array}{l}\text { word- } \\
\text { guide }\end{array}$ & Element & Deviation & Causes & Consequences & $\begin{array}{l}\text { Barriers } \\
\text { security }\end{array}$ & G & $\mathrm{P}$ & $\mathrm{R}$ & Events & $\begin{array}{l}\text { Correctives } \\
\text { action }\end{array}$ \\
\hline
\end{tabular}

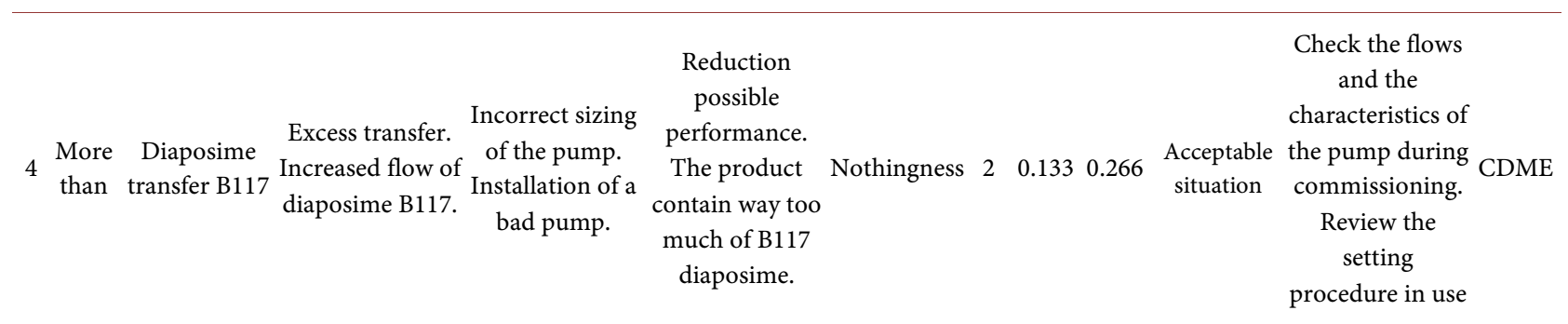




\section{Continued}

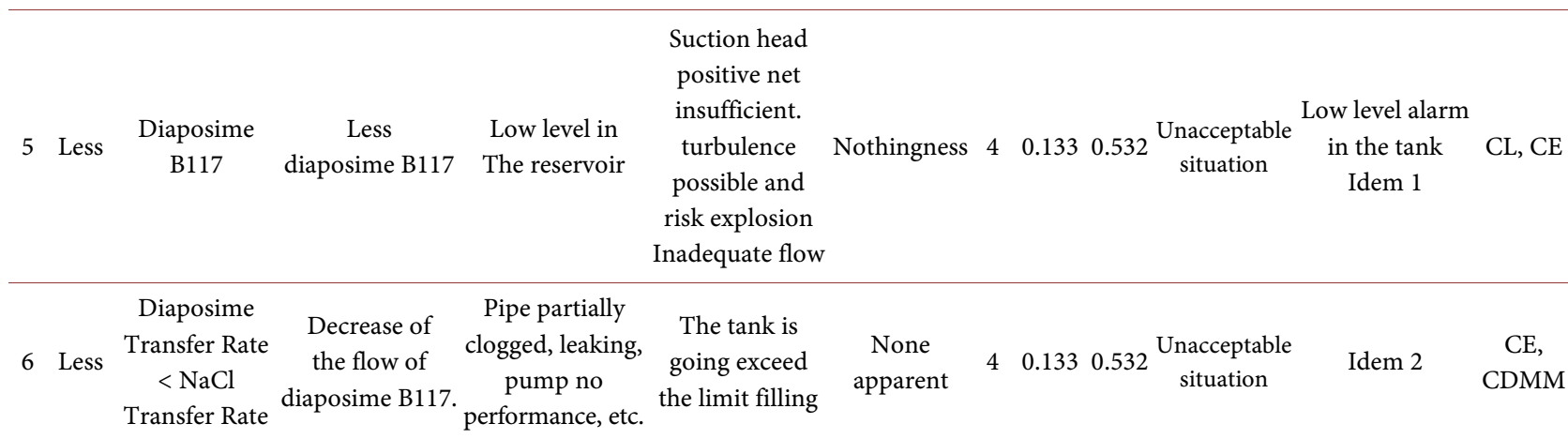

Table 7. HAZOP Worksheets 3/4.

Title of the study: Water treatment process

Worksheets: $3 / 4$

Drawing $\mathrm{N}^{\circ}$ :

Date: $26 / 05 / 2021$

Line-up: CE, CL, CDME, CDMM, CG, SMH

Meeting date: $20 / 05 / 2021$

Party considered: Transfer duct from the supply tank of the diaposime to the boilers

Material: Diaposime B117

Source: Diaposime B117 tank

Activity: Transfer continuously at a rate greater than that of $\mathrm{NaCl}$

Operating parameters: Pressure, temperature and flow

\begin{tabular}{|c|c|c|c|c|c|c|c|c|c|c|c|c|}
\hline $\mathrm{N}^{\circ}$ & $\begin{array}{l}\text { Word } \\
\text { guide }\end{array}$ & Element & Deviation & Causes & Consequences & $\begin{array}{l}\text { Barriers } \\
\text { security }\end{array}$ & G & $\mathrm{P}$ & $\mathrm{R}$ & Events & $\begin{array}{l}\text { Corrective } \\
\text { action }\end{array}$ & Resp \\
\hline 7 & $\begin{array}{c}\text { In } \\
\text { addition } \\
\text { to }\end{array}$ & $\begin{array}{l}\text { Diaposime } \\
\text { B117 }\end{array}$ & $\begin{array}{l}\text { In addition to } \mathrm{D} \text {, a } \\
\text { other fluid is also } \\
\text { present in the tank } \\
\text { supply. }\end{array}$ & $\begin{array}{l}\text { procurement } \\
\text { of tank } \\
\text { contaminated }\end{array}$ & Unknown & $\begin{array}{l}\text { Verification } \\
\text { and analysis } \\
\text { content from all } \\
\text { feed tank before } \\
\text { unloading in } \\
\text { the supply tank. }\end{array}$ & 4 & 0.4 & 1.6 & $\begin{array}{c}\text { Unacceptable } \\
\text { situation }\end{array}$ & $\begin{array}{l}\text { Check the } \\
\text { procedure of } \\
\text { operation }\end{array}$ & CL \\
\hline \multirow{4}{*}{8} & \multirow{4}{*}{$\begin{array}{l}\text { In } \\
\text { addition } \\
\text { to }\end{array}$} & \multirow{4}{*}{$\begin{array}{l}\text { Diaposime } \\
\text { transfer }\end{array}$} & \multirow{4}{*}{$\begin{array}{l}\text { In addition to the } \\
\text { Diaposime } \\
\text { transfer, } \\
\text { something is } \\
\text { passes: corrosion, } \\
\text { erosion, } \\
\text { crystallization or } \\
\text { decomposition }\end{array}$} & \multirow{4}{*}{$\begin{array}{l}\text { Low level in } \\
\text { The reservoir }\end{array}$} & Suction head & Nothingness & 4 & 0.4 & 1.6 & $\begin{array}{c}\text { Unacceptable } \\
\text { situation }\end{array}$ & Idem 5 & \\
\hline & & & & & $\begin{array}{l}\text { positive net } \\
\text { insufficient. } \\
\text { turbulence }\end{array}$ & Nothingness & 4 & 0.4 & 1.6 & $\begin{array}{c}\text { Unacceptable } \\
\text { situation }\end{array}$ & Idem 5 & \\
\hline & & & & & \multirow{2}{*}{$\begin{array}{c}\text { turbulence } \\
\text { possible and risk } \\
\text { explosion } \\
\text { Inadequate flow }\end{array}$} & Nothingness & 4 & 0.4 & 1.6 & $\begin{array}{c}\text { Unacceptable } \\
\text { situation }\end{array}$ & Idem 5 & \\
\hline & & & & & & Nothingness & 4 & 0.4 & 1.6 & $\begin{array}{c}\text { Unacceptable } \\
\text { situation }\end{array}$ & Idem 5 & \\
\hline 9 & $\begin{array}{c}\text { In } \\
\text { addition } \\
\text { to }\end{array}$ & $\begin{array}{c}\text { Destination } \\
\text { streamers }\end{array}$ & $\begin{array}{c}\text { In addition to } \\
\text { destination of the } \\
\text { coils External leaks }\end{array}$ & $\begin{array}{l}\text { Leak in the } \\
\text { led, the valve } \\
\text { or the seal } \\
\text { mechanics of } \\
\text { the pump }\end{array}$ & $\begin{array}{l}\text { Contamination of } \\
\text { the environment. } \\
\text { Risk of explosion }\end{array}$ & $\begin{array}{l}\text { Use a code or } \\
\text { of a standard } \\
\text { approved for } \\
\text { the } \\
\text { Pipelines }\end{array}$ & 4 & 0.4 & 1.6 & $\begin{array}{c}\text { Unacceptable } \\
\text { situation }\end{array}$ & $\begin{array}{l}\text { Position the } \\
\text { flowmeter for } \\
\text { the release } \\
\text { as close as } \\
\text { possible coils }\end{array}$ & $\begin{array}{c}\mathrm{CE}, \\
\mathrm{CDM} \\
\mathrm{M}\end{array}$ \\
\hline
\end{tabular}

The risk $R$ as well as the probability of occurrence $P$ of event $\mathrm{B}$ being very high, then there is a need to pay more attention to the equipment which is likely to suffer the harmful consequences in the event of the occurrence of event $B$ (Figure 2). 
Table 8. HAZOP Worksheets $4 / 4$.

Title of the study: Water treatment process

Drawing $\mathrm{N}^{\circ}$ :

Line-up: CE, CL, CDME, CDMM, CG, SMH
Worksheets: $4 / 4$

Date: $26 / 05 / 2021$

Meeting date: $20 / 05 / 2021$

Party considered: Transfer duct from the supply tank of the diaposime to the boilers

Material: Diaposime B117

Source: Diaposime B117 tank

Activity: Transfer continuously at a rate greater than that of $\mathrm{NaCl}$ Destination: Streamers

Operating parameters: Pressure, temperature and flow

\begin{tabular}{|c|c|c|c|c|c|c|c|c|c|c|c|c|}
\hline $\mathrm{N}^{\circ}$ & $\begin{array}{l}\text { Word } \\
\text { guide }\end{array}$ & Element & Deviation & Causes & Consequences & $\begin{array}{l}\text { Barriers } \\
\text { security }\end{array}$ & G & $\mathrm{P}$ & $\mathrm{R}$ & Events & $\begin{array}{c}\text { Corrective } \\
\text { action }\end{array}$ & Resp \\
\hline 10 & Inverted & $\begin{array}{c}\text { Transfer } \\
\text { Diaposime } \\
\text { B117 }\end{array}$ & $\begin{array}{l}\text { Inversion of the } \\
\text { direction of flow. } \\
\text { The treated water } \\
\text { flows from the } \\
\text { coils to the tank } \\
\text { supply }\end{array}$ & $\begin{array}{l}\text { Pressure in the } \\
\text { coils superior to } \\
\text { the pressure } \\
\text { evacuation } \\
\text { the pump }\end{array}$ & $\begin{array}{l}\text { Contamination } \\
\text { of tank supply } \\
\text { by reflux } \\
\text { material from } \\
\text { reaction }\end{array}$ & $\begin{array}{c}\text { None } \\
\text { apparent }\end{array}$ & 3 & 0.067 & 0.201 & $\begin{array}{c}\text { Unacceptable } \\
\text { situation }\end{array}$ & $\begin{array}{c}\text { Provide } \\
\text { installing a } \\
\text { check valve } \\
\text { in driving }\end{array}$ & $\mathrm{CE}$ \\
\hline 11 & $\begin{array}{l}\text { Other } \\
\text { than }\end{array}$ & $\begin{array}{l}\text { Diaposime } \\
\text { B117 }\end{array}$ & $\begin{array}{c}\text { Other than } \\
\text { Diaposime B117. } \\
\text { Material other } \\
\text { that the } \\
\text { Diaposime B117 } \\
\text { in the tank } \\
\text { supply }\end{array}$ & $\begin{array}{l}\text { Bad material } \\
\text { in the tank } \\
\text { supply }\end{array}$ & $\begin{array}{l}\text { unknown } \\
\text { Function of } \\
\text { material }\end{array}$ & $\begin{array}{l}\text { Controls } \\
\text { and analyzes } \\
\text { of the nature } \\
\text { of content of } \\
\text { the tanker } \\
\text { before } \\
\text { unloading }\end{array}$ & 4 & 0.133 & 0.532 & $\begin{array}{c}\text { Acceptable } \\
\text { situation }\end{array}$ & & CE, CL \\
\hline 12 & $\begin{array}{l}\text { Other } \\
\text { than }\end{array}$ & $\begin{array}{l}\text { Reactor of } \\
\text { destination }\end{array}$ & $\begin{array}{c}\text { External leak } \\
\text { Nothing happens } \\
\text { to boilers }\end{array}$ & Conduct break & $\begin{array}{c}\text { Contamination } \\
\text { of the } \\
\text { environment } \\
\text { and risk of } \\
\text { explosion }\end{array}$ & $\begin{array}{l}\text { Integrity of } \\
\text { pipelines }\end{array}$ & 4 & 0.133 & 0.532 & $\begin{array}{l}\text { Acceptable } \\
\text { situation }\end{array}$ & $\begin{array}{l}\text { Specify that } \\
\text { the detector } \\
\text { flow proposed } \\
\text { is enough fast } \\
\text { to release to } \\
\text { avoid a } \\
\text { explosion }\end{array}$ & $\begin{array}{l}\text { CDME, } \\
\text { CDMM }\end{array}$ \\
\hline
\end{tabular}
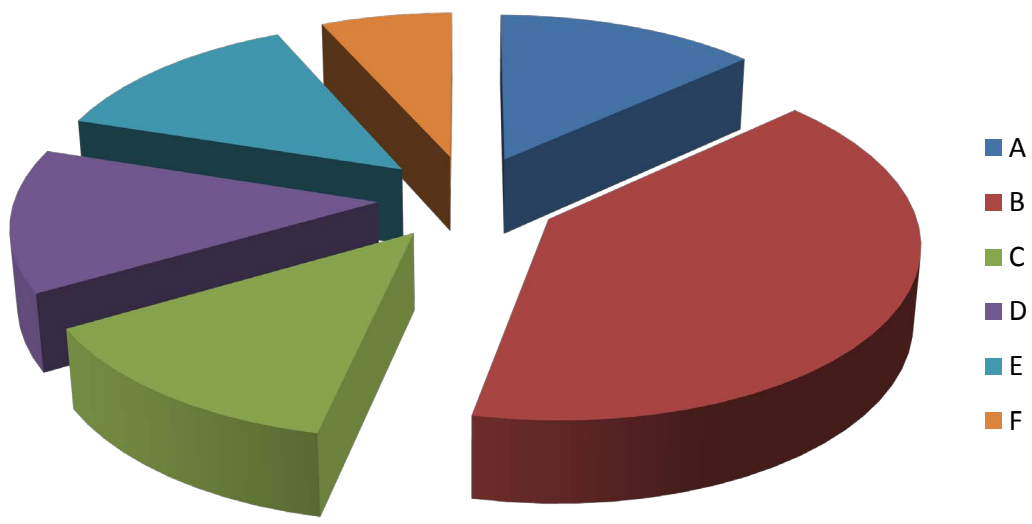

Figure 2. Sectors of interpretation of the probabilities of occurrence.

Then the importance will be given to the equipment which is likely to undergo the harmful effects of events A, C, D, E (Table 4).

Finally, it is the turn of the equipment that will suffer failures in case the oc- 
currence of event F. It should be noted that the analysis was carried out on the boilers of a single thermal power station, in particular that of BWSC \& MAN, in order to extrapolate it to the other thermal power stations.

\subsection{Evaluation of the Operating Reliability of the Existing System by the Fault Tree}

The determination and quantification of the various failures were carried out with the collaboration of technicians from the thermal production department (Table 9).

Table 9. Components of the failure tree.

\begin{tabular}{|c|c|c|}
\hline Landmarks & Designations & Levels \\
\hline A & Lack of feed water in the coils & Very low \\
\hline B & Unavailability of boilers for maintenance & Frequent \\
\hline $\mathrm{C}$ & Drilled Steam Rails & Medium \\
\hline $\mathrm{D}$ & Runs exploded & Very low \\
\hline $\mathbf{E}$ & Steam Balloon Feeding Pumps & Medium \\
\hline $\mathbf{F}$ & Faulty backup pump & Low \\
\hline G & Pierced Coils & Low \\
\hline $\mathrm{H}$ & Pumps supplying defective coils & Low \\
\hline I & Steam vapor balloon & Very low \\
\hline $\mathrm{J}$ & B117 diaphragm pump failed & Very low \\
\hline $\mathrm{K}$ & Pump $\mathrm{NaCl}$ (salt) failed & Very low \\
\hline $\mathrm{L}$ & Abnormal value of pressure & Frequent \\
\hline $\mathbf{M}$ & Abnormal temperature value & Frequent \\
\hline $\mathbf{N}$ & Lack of feed water in the steam flask & Low \\
\hline O & $\begin{array}{l}\text { Unavailability due to short circuit feedback (high } \\
\text { pressure alarm) }\end{array}$ & Medium \\
\hline $\mathbf{P}$ & Defective contactor (high pressure alarm) & Medium \\
\hline Q & Failed High Pressure Alarm & Frequent \\
\hline $\mathbf{R}$ & $\begin{array}{l}\text { Unavailability due to short circuit feedback (high } \\
\text { temperature alarm) }\end{array}$ & Medium \\
\hline $\mathrm{S}$ & Defective contactor (high temperature alarm) & Medium \\
\hline $\mathbf{T}$ & Fail high temperature alarm & Frequent \\
\hline
\end{tabular}

The different scenarios (Scenes) (Figure 3) are: Scenes 1 “A, N, I, E, F”; Scene 2 “A, H"; Scene 3 "A, G”; Scene 4 "B"; Scene 5 "C"; Scene 6 "D, M, R, S, T"; Scene 7 "D, L, O, P, Q"; Scene 8 “D, J"; Scene 9 “D, K”.

This fault tree is a general overview of the faults likely to occur on the boilers/steam circuits of each SPTN generator set. 


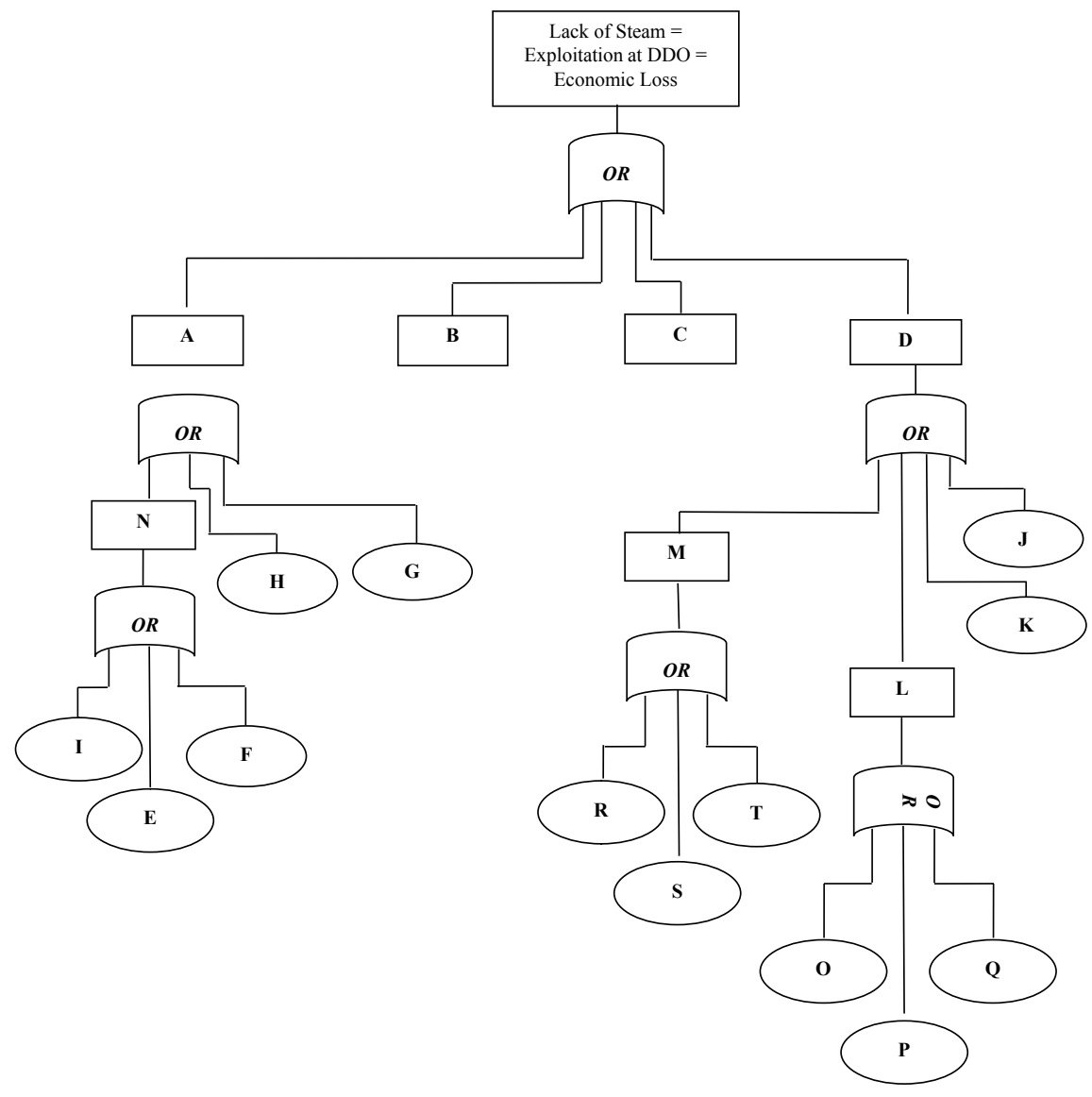

Figure 3. Fault tree.

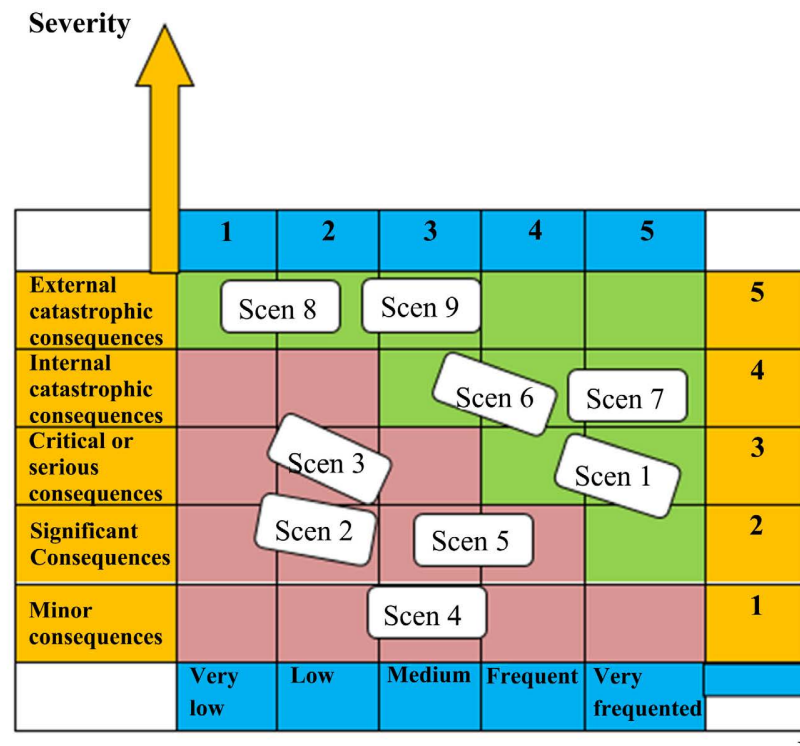

Assumed risk

Probability of

Occurrence

\section{Unacceptable risk}

Figure 4. Risk estimation. 
By analyzing the fault tree, we realize that the interconnection of the vapor circuits would reduce the effects of the probability of occurrence of the "Lack of vapor" event. If the event occurs, this reduction in effects is achieved by transferring steam from a generator set in operation to the generator set whose boiler is failing.

The estimation of the various risks leads us to carry out their sizing according to the types of risk, namely the "Assumed risk" and the "Unacceptable risk" as illustrated in Figure 4.

In addition, we carry out the risk calculations as shown in Table 10 below.

Table 10. Risks Calculation.

\begin{tabular}{|c|c|c|c|}
\hline Landmarks & $\begin{array}{c}\text { Probability } \\
(P)\end{array}$ & $\begin{array}{l}\text { Severity } \\
(G)\end{array}$ & $\begin{array}{l}\text { Risks }(R) \\
R=P \times G\end{array}$ \\
\hline A & $9.01 \times 10^{-3}$ & 2 & $18.02 \times 10^{-3}$ \\
\hline B & $4 \times 10^{-2}$ & 1 & $4 \times 10^{-2}$ \\
\hline $\mathrm{C}$ & $3 \times 10^{-3}$ & 3 & $9 \times 10^{-3}$ \\
\hline $\mathrm{D}$ & $93 \times 10^{-3}$ & 5 & $465 \times 10^{-3}$ \\
\hline $\mathrm{E}$ & $3 \times 10^{-3}$ & 1 & $3 \times 10^{-3}$ \\
\hline $\mathrm{F}$ & $2 \times 10^{-3}$ & 2 & $4 \times 10^{-3}$ \\
\hline G & $2 \times 10^{-3}$ & 5 & $10 \times 10^{-3}$ \\
\hline $\mathrm{H}$ & $2 \times 10^{-3}$ & 4 & $8 \times 10^{-3}$ \\
\hline I & $1 \times 10^{-5}$ & 4 & $4 \times 10^{-5}$ \\
\hline $\mathrm{J}$ & $1 \times 10^{-4}$ & 5 & $5 \times 10^{-4}$ \\
\hline K & $1 \times 10^{-4}$ & 5 & $5 \times 10^{-4}$ \\
\hline $\mathrm{L}$ & $46 \times 10^{-3}$ & 2 & $92 \times 10^{-3}$ \\
\hline M & $46 \times 10^{-3}$ & 2 & $92 \times 10^{-3}$ \\
\hline $\mathrm{N}$ & $5.01 \times 10^{-3}$ & 2 & $10.01 \times 10^{-3}$ \\
\hline $\mathrm{O}$ & $3 \times 10^{-3}$ & 2 & $6 \times 10^{-3}$ \\
\hline $\mathrm{P}$ & $3 \times 10^{-3}$ & 2 & $6 \times 10^{-3}$ \\
\hline Q & $4 \times 10^{-2}$ & 2 & $8 \times 10^{-2}$ \\
\hline $\mathrm{R}$ & $3 \times 10^{-3}$ & 2 & $6 \times 10^{-3}$ \\
\hline$S$ & $3 \times 10^{-3}$ & 2 & $6 \times 10^{-3}$ \\
\hline $\mathrm{T}$ & $4 \times 10^{-2}$ & 2 & $8 \times 10^{-2}$ \\
\hline
\end{tabular}

Note that the probability of occurrence $P$ is obtained by multiplying the coefficient of level $c$ by the probability $p$ between an interval $(P=p \times c)$. Confers table of the level of probability of occurrence. From the foregoing it follows that:

$$
R=P \times G=p \times c \times G
$$

The events $\mathrm{N}, \mathrm{A}, \mathrm{M}, \mathrm{L}, \mathrm{D}$ being respectively the unions of the following sets of events: $\{I, E, F\} ;\{N, H, G\} ;\{R, S, T\} ;\{O, P, Q\} ;\{L, M, J, K\}$. 
The respective gravities of the events N, A, M, L, D are not deduced respectively from the sets of events mentioned above but directly on the table of the level of severity of the undesired events.

Then their probabilities are deduced from the following formulas:

$$
\begin{gathered}
P(\mathrm{~N})=P(\mathrm{I})+P(\mathrm{E})+P(\mathrm{~F}) ; \\
P(\mathrm{~A})=P(\mathrm{~N})+P(\mathrm{H})+P(\mathrm{G}) ; \\
P(\mathrm{M})=P(\mathrm{R})+P(\mathrm{~S})+P(\mathrm{~T}) ; \\
P(\mathrm{~L})=P(\mathrm{O})+P(\mathrm{P})+P(\mathrm{Q}) ; \\
P(\mathrm{D})=P(\mathrm{~L})+P(\mathrm{M})+P(\mathrm{~J})+P(\mathrm{~K}) ;
\end{gathered}
$$

The probability $P$ that there is a lack of steam is therefore given by the following formula:

$$
\begin{gathered}
P=P(\mathrm{~A})+P(\mathrm{~B})+P(\mathrm{C})+P(\mathrm{D}) \\
P=18.02 \times 10^{-3}+4 \times 10^{-2}+9 \times 10^{-3}+465 \times 10^{-3} \\
P=532.02 \times 10^{-3}
\end{gathered}
$$

As the probability $P$ is very high, there is therefore a need to interconnect the boilers of the generator sets of the various thermal power stations of the SPTN. It should be noted that the analysis was carried out on the boilers of a single generator set in particular that of BWSC \& MAN, in order to extend it to the other boilers.

\section{Conclusions}

The risk analysis presented in this work is a considerable contribution to controlling the management of industrial risks in the steam production process, with a view to optimizing the probability of occurrence of unwanted events.

This study allowed us to look for the possible causes of derivatives of the various operating parameters as well as to determine the possible consequences and risks, a practice of identifying dangers and operational problems adopted by many industries.

In addition, the risk assessment in the thermal production process has enabled us to easily realize that the number of incidents can be reduced. We can also save on time losses due to various unplanned shutdowns and a general overview of other components that may experience failures in the thermal production system.

\section{Acknowledgements}

The author would like to thank all reviewers for their valuable comments on this thesis, which allowed us to find many details worthy of improvement and made our paper more clear and complete.

\section{Conflicts of Interest}

The authors declare no conflicts of interest regarding the publication of this paper. 


\section{References}

[1] Sirima, M.H., Naon, B., Bationo, F., Soulama, S.R. and Wambua, P. (2019) Design of a Continuous Forced Convection Indirect Solar Dryer with Supplementary Heating for the Drying of Agricultural Products: Maize, Mahogany Nuts, Shea Nuts, Mangoes By-Products. Applied Engineering, 3, 95-101.

[2] Sirima, M.H., Naon, B. and Bationo, F. (2019) Thermal Regulation in an Interconnection of Thermal Plant Steam Circuits: Case of the Three Thermal Power Plants of the Burkina Faso Northern Ouaga Production Service (Sptn). Applied Engineering, 3, 102-106.

[3] Sirima, M.H., Naon, B. and Wambua, P. (2019) Regulation and Thermal Compensation of a Continuous Forced Convection Indirect Solar Dryer for the Drying of Agricultural Products: Maize, Mahogany Nuts, Shea Nuts, By-Products Derived from the Processing of Mango. Applied Engineering, 3, 119-124.

[4] Sirima, M.H., Naon, B. and Bationo, F. (2019) Interconnection of Thermal Plant Steam Circuits: Case of the Three Thermal Plants of the Burkina Faso Northern Ouaga Production Service (Sptn). Applied Engineering, 3, 107-113.

[5] Basu, S. (2017) Failure Tree: Definition Objectives and Fields of Application/Examples.

[6] Brini, M., Crubille, P., Lussier, B. and Schön, W. (2017) Safety Constraints for the Safety-Bag of an Autonomous Vehicle: FMEA and HazOp Methods. 12 th International Pluridisciplinary Congress on Quality, Dependability and Substainability (QUALITA 2017), Bourges, France, August 2017, 9 p.

[7] Drexler, P., Faatz, H., Feicht, F., Geis, H., Morlok, J. and Wiesmann, E. (1988) Study and Design of Hydraulic Facilities. Mannesmann Rexroth GmbH, Lohr am Main/ Federal Republic of Germany (FRG), Loh ram Main, Federal Republic of Germany, $337 \mathrm{p}$.

[8] Spirax Sarco (2015, July) Spirax Sarco Worldclass-Worldwide (Fluidic Circuit Sizing). Spirax Sarco, 25 p.

[9] Zwingelstein, G. (2019) Dependability of Complex Systems. Engineering Technique, Industrial IT, $32 \mathrm{p}$.

[10] Thollin, B. (2013) Electrothermal Characterization Tools and Methodologies for the Analysis of Power Electronics Interconnection Technologies. Ph.D. Thesis, the University of Grenoble, Grenoble, France, 158 p. 